Impact Factor: 4.845(SJIF) Research Journal Of English (RJOE) Vol-5, Issue-2, 2020

www.rjoe.org.in An International Peer-Reviewed English Journal

ISSN: 2456-2696

Indexed in: International Citation Indexing (ICI), International Scientific Indexing (ISI), Directory of Research Journal Indexing (DRJI) Google Scholar \& Cosmos.

\title{
ESTRANGEMENT IN SELECT NOVELS OF TONI MORRISON
}

\author{
Jyothi $\mathbf{R}^{\mathbf{1}}$ \\ Acharya Nagarjuna University, Department of English Guntur, India \\ Dr Pankaj Kumar $\mathbf{K}^{2}$ \\ Department of English, Acharya Nagarjuna University, India
}

\begin{abstract}
:
Toni Morrison's novels aim to critique the parable of black inferiority and subordination which prevails in largely white culture. "Her novels investigate the devastating effects of the sweetness standards of the dominant culture on the egos of the African - female adolescent. Toni Morrison's novles are, quest tales during which key characters look for the hidden sign, capable of giving them strength and identity Toni Morrison's shows the exploitative nature of logo centric orders. Her novels are exploration of the meaning of Blackness. She wants the reader to figure jointly with the author in formulating the meaning of her novels. She puts forward the characters, which are evacuated to the margins of the society, in the name of their race and gender alienation". She also brings them out of the anonymity and narrates their own history in their own words. She also assesses the core of the African American reality particularly that of an African female and female alienation, feminist issues in most of her novels.
\end{abstract}

Keywords: Racism, dominant culture, female adolescent, black inferiority, white culture.

\section{Introduction:}

This research is a study of the issues of alienation of African American women who were transported as slaves to The United States. This thesis is a study of "the issues of alienation of African American women who were transported as slaves to The United States. It focuses on their physical and mental tortures from the white men and women because of their Blackness. The cruelty to the Black women from men, both Black and white is explored. It investigates the struggles of Black women in their look for identity and their failures in achieving their identity. Toni Morrison has distinguished herself as an author, editor and critic who has transformed the American literary landscape with her presence in the African American literary tradition. Toni Morrison helped to market Black Literature and authors when she worked as an editor for Random House within the 1960's and 1970's. Morrison herself emerged together of the foremost renowned African American writer within the twentieth century. She has written ten novels. Toni Morrison's works have taken 
Impact Factor: 4.845(SJIF) Research Journal Of English (RJOE) Vol-5, Issue-2, 2020

www.rjoe.org.in An International Peer-Reviewed English Journal

ISSN: 2456-2696

Indexed in: International Citation Indexing (ICI), International Scientific Indexing (ISI), Directory of Research Journal Indexing (DRJI) Google Scholar \& Cosmos.

her to the skies. She had genuinely portrayed the true voice of African - American slave life. She keeps her people in touch with myths, which enable them to act out their potential recuperate and portray their inner spiritual imaginative lives hidden beneath historical facts. 'Toni Morrison' asserts the importance of identity, speaking out against racism, sexism and silencing. She explores the deep layers of everyday texture of people's lives, emphasizing the lives of victims and strong imaginative energetic women and men". She creates historical reality when she reveals the energies, hardships and experiences of Black men and ladies. Her famous novel Beloved won the Pulitzer Prize for fiction. Toni Morrison is that the first African American woman to win the Nobel prize for Literature in 1993.

Toni Morrison deals with the themes of affection and friendship, look for identity, concept of beauty and ugliness, and life and death in her novels. "Her heroines and heroes struggle to know all the higher aspects of the human conditions. The theme which is common in her novels is alienation. Alienation proves to be a devastating phenomenon for the Black women in America. Being away from their own land, they are tied with the chains of slavery.The Black women are portrayed as breeding women, maids and domestic workers. Black women are viewed and treated just as the commodities to be handled by the white masters. They were not allowed to have any human rights whatsoever. But their white masters have all rights over them”. They are forced to measure during a set-up which is filled with racism and sexism, which end in alienation.

In Toni Morrison's The Bluest Eye, Pecola is kept faraway from her parents, classmates and therefore the large society. In her second novel Sula, "Morrison depicts the search of the protagonist Sula creating her own self and coming to terms together with her identity as a Black and also a woman. The novel demonstrates the difficulties that the Black women face once they attempt to explore different aspects of their lives. Sula is alienated. She believes that she can create an identity for herself and she lives out of her community and social expectations. In Beloved, Sethe is kept in isolation by the masters of sweet home and by the black men in Ohio. She is haunted by her dead daughter Beloved at the end. New Historicist Criticism may as an example help, shed light on Morrison's writing because it looks at a work's discourse as something which is strongly linked to the society in which the author has created it.

The gender codes in Sula, the oppressive environment in The Bluest Eye, and the complexity of sexuality and love in Beloved can all be recognized as aspects of the society of the 20 th century, not only familiar to the author, but also to the reader". The reader too, is strongly linked to society - its ideology and belief systems and can understand a piece of literature accordingly. As the "American Version Of Cultural Studies" shows: "Its sympathy for disadvantaged, 'marginalized' people...”(179). Toni Morrison clearly demonstrates in her literature a sympathy for marginalized people through her portrayal of the most vulnerable 
Impact Factor: 4.845(SJIF) Research Journal Of English (RJOE) Vol-5, Issue-2, 2020

www.rjoe.org.in An International Peer-Reviewed English Journal

ISSN: 2456-2696

Indexed in: International Citation Indexing (ICI), International Scientific Indexing (ISI), Directory of Research Journal Indexing (DRJI) Google Scholar \& Cosmos.

members of society such as the children and the women in her fiction. She also clearly draws parallels between the oppression of Blacks in America and therefore the oppression within the Black communities.

The use of a social and cultural approach when analyzing Morrison is thus helpful, as her writing portrays behaviour as a social and cultural construct. As Griffiths puts it, "In an anthropological sense, "culture" is that the total way of lifetime of a specific society - its language, economy ... a set of codes that everyone during a society shares and allows them to speak ..." (179-180). The colloquial language that for example "Morrison applies in her discourse is an example of how she draws on different aspects of black culture, which help to make her stories representative of the time and place during which the stories are set. She also uses, as part of her discourse, inter textual references, such as nursery rhymes, historical references from the civil rights era, and iconic figures like Shirley Temple, which help to place her characters in a specific environment and at a particular time. The culture and society of the cosey's are for example illustrated through Heed's language, which reveals her to be an intruder and an outsider in the family, as both her spoken language and her writing skills are poor. Morrison lets the young Christine ridicule Heed's use of language when eager to set herself above her former friend. People with power - social, economic . . . use discourse to control people and maintain their own power" (Griffiths, 180). Other examples of how codes of behaviour are used to reveal differences in class and power in Morrison's fiction are, the social conduct in Sula, which serves to separate sula from the common blacks within the Bottom, also as Geraldine's assertion of superiority in her meeting with Pecola within the Bluest Eye.

As Griffiths notes: "Power elites are often persons within a society - wealthy persons, politicians, White race , males... Thus, some people are "marginalized" and made susceptible to exploitation". (180-181) Racism, patriarchy and sexism are a part of the ideology within the societies that Morrison portrays. By telling "the stories of a young girl's exposure to sexual harassment and how this affects them, and by showing how marginalized people in The Bluest Eye like the poor Breedlove's, along with the prostitutes, are made vulnerable by the norms of society, Morrison's writing explains human behaviour as something which is the result of oppression and marked by social and cultural constructs. As Raynor and Butler means : critics examine how Morrison ... illustrates the destructive nature of patriarchy both within the mainstream of yank society and African American communities. Morrison's novels serve as historical "narratives by showing the links among gender, race, and class. (178) In Sula all the main characters are women. We follow the most character Sula from her early teens within the year 1921 to her death in 1940, from being a lonely female child to someone who due to her promiscuous behaviour has at the time of her death become the object of hatred and superstition in the Bottom society (the Black, segregated part of the town of Medallion where Sula lives). Sexuality proves to be a problem 
Impact Factor: 4.845(SJIF) Research Journal Of English (RJOE) Vol-5, Issue-2, 2020

www.rjoe.org.in An International Peer-Reviewed English Journal

ISSN: 2456-2696

Indexed in: International Citation Indexing (ICI), International Scientific Indexing (ISI), Directory of Research Journal Indexing (DRJI) Google Scholar \& Cosmos.

also in Sula's friendship to Nel, a friendship which Sula within the end ruins by sleeping with Nel's husband. The main character Sula isn't , however, introduced by Morrison until 1922, after the character Shadrack is presented in 1919, and Sula's ally Nel in 1920. It is evident that Morrison uses this manner of opening to characterize the environment during which Sula grows up, and which has shaped Sula's character, personality and sexuality". Sula stands con to the perfect of a lady because her desire isn't towards getting married or having children. Friendship with Nel is Sula's first choice. Nevertheless, when Sula loses $\mathrm{Nel}$ to a person, she is willing to seek out a replacement life for herself faraway from her family and community.

But not finding what she had been looking for, she comes back to Medallion ten years later. Sula quickly recognizes what proportion has changed between her and Nel during her absence. Sula is disappointed to seek out Nel living an equivalent life as everyone else does; Sula cannot accept the very fact that her friend is now as boring as all the other women within the town which Nel "had given herself over to them" (S120). Sula shows how a Black community develops and shapes itself within its own cultural resources. It is about the friendship of two Afro-American girls Nel and Sula, from their childhood to adulthood. However, in Sula, Morrison creates a robust female character who "not only refuses the role (the standard role assigned for a woman), she steps outside the cast of woman, beyond any class or definition and insists on making herself' (Christian 76). Sula won't surrender to the assigned role and she or he counts on her friendship bond with Nel because this bond allows both Nel and Sula to fight against oppression; but the 2 women separate in their adulthood due to the various roles they take up in their community. Christian argues that "African American women who internalize the dominant society's definition of girls are courting selfdestruction" (79). In Sula Morrison critiques motherhood because the Black community's primary definition of woman. Sula depicts, among other things, the importance of female friendship because when men are absent and preoccupied with their own struggle to win their manhood back, women got to stick together and support one another so as to survive and so as to beat the obstacles life brings them.

Female friendships also are central in Morrison's works, and particularly within the novels of my investigation. In both Sula and Beloved, friendship between lonely little girls and later women serve as background for studying the effects of thwarted sexual behaviour on vulnerable individuals. In both novels these friendships last a lifetime. "In The Bluest Eye, there's also a special friendship among little girls, where Frieda and Claudia attempt to rescue Pecola. The fate of Pecola, however, is so devastating that a mutual and lasting friendship between her and therefore the two sisters is beyond reach. The interpersonal relationships among the characters in Toni Morrison's second novel Sula suggest that African Americans still face many difficulties when trying to assimilate into the American mainstream society. Discrimination of African Americans is still strong which is clearly 
Impact Factor: 4.845(SJIF) Research Journal Of English (RJOE) Vol-5, Issue-2, 2020

www.rjoe.org.in An International Peer-Reviewed English Journal

ISSN: 2456-2696

Indexed in: International Citation Indexing (ICI), International Scientific Indexing (ISI), Directory of Research Journal Indexing (DRJI) Google Scholar \& Cosmos.

visible in the denial of job opportunities for African American inhabitants of Medallion. The Bottom's men fear of emasculation and their attempts to win respect of the dominant society result in the men's frustrations which they consequently project in their personal relationships with African American women and with their children. The major problem of the novel's characters is their acceptance of the dominant society's ideas of masculinity and femininity and their submission to the dominant society's views of marriage and social roles. Most male characters in the novel look for a submissive woman who would help them feel better about their own masculinity. The only male character who is not interested in proving anything to the mainstream society and who does not accept the defined notions of masculinity and femininity is Ajax, who leads a better off and satisfactory life than the remainder of the lads within the Bottom. Women's fears of being alone and unloved force them to simply accept sexist oppression and to undergo the menial position.

Nel Wright represents the submissive female character. Her got to nurture and to be needed by someone force her to calm down. Nel isn't questioning her position within the society and she or he surrenders to the role of a wife and a mother and believes that these roles will make her life complete". However, the other becomes true because in her marriage with Jude, Nel must constantly comply to her husband's demands and she or he only lives to form him happy and to take care of their children. Jude is one among the community's men who is willing to prove his masculinity by getting an appropriate working position and by having a wife. "In his marriage to Nel, Jude is not looking for an equal companion, he is looking for someone he can dominate. Jude's view of marriage and Nel's submission to it consequently result in the reduction of Nel's personality. Male / female relationships portrayed within the novel are supported cultural conditioning and obligation quite a free choice. Motherhood also represents the connection which is predicated on cultural conditioning and obligation. When male characters leave their families, African American women are left without support or protection from African American men and thus, African American women within the novel must take care of their families on their own and are put within the position of a family provider.

The lack of the support, African American mothers receive projects within the mother's ways of expressing affection to their children. Consequently, the relationships between mothers and their children become complicated because mothers fail to speak about their struggles with their children and youngsters miss their mothers' affection. Motherhood doesn't represent a satisfying relationship in Sula. Sula sees things for what they truly are and she understands the dynamics of male / female and mother / daughter relationships. Sula comprehends the fact that relationships with men involve the reduction of women's personalities and that being a mother involves an enormous sacrifice on the side of mothers. Sula believes that it is better for a woman to live without a man and she becomes an outcast in her community. Nonetheless, even Sula is forced to experience the necessity to possess 
Impact Factor: 4.845(SJIF) Research Journal Of English (RJOE) Vol-5, Issue-2, 2020

www.rjoe.org.in An International Peer-Reviewed English Journal

ISSN: 2456-2696

Indexed in: International Citation Indexing (ICI), International Scientific Indexing (ISI), Directory of Research Journal Indexing (DRJI) Google Scholar \& Cosmos.

and therefore the absence of a person in her relationship with the sole man of the community who does not reject her. The community's men give Sula the ultimate label because she poses a threat to their masculinity. The differences between Sula's and Nel's view of marriage, motherhood, and a woman's role within the society become the most cause for his or her estrangement".

However, Sula values her friendship with Nel because in contrast to male / female relationships and mother / daughter relationships, women's friendship involves equality of participation and is predicated on free choice. "Nel represents Sula's center in childhood and these two girls find the sense of belonging in each other's company. The girls realize at a young age that their situation within the society is complicated because they're African American females. Sula and Nel help one another, define their personalities, they supply one another with the protection they lack and that they fight against oppression together. The girls feel safe in each other's company and they complement each other. Sula never competes with Nel and sees Nel as an important and equal person. Neither Sula nor Nel find this type of protection, understanding, and equality in their relationships with men. To conclude, women's friendship is that the only relationship within the novel which doesn't involve the reduction of personalities and therefore the only relationship which supports a healthy growth of characters". The fact that the feminine characters within the novel are left alone which they experience the absence of male characters intensifies the importance of women's bonding.

Women's friendship helps the 2 female characters see that they're not alone in facing the life's obstacles in their adolescent years and their friendship enables them to deal with social expectations. "Nevertheless, most female characters do not appreciate women's bond. But when there is a lack of women's bonding, women's lives in the novel are not fulfilling. Toni Morrison portrays the friendship of Sula and Nel in the novel to show that if women cultivated women's bonds, they would be able to fight against oppression. Slave women were wretchedly abused. The Black Women Writers have documented how the black women were made 'Breeders'. Their masters use them for their sexual hunger and they are subjected to public fondling and exposed naked on the auction block W.E.B.Du Bois says:" A slave woman is treated as an unwed mother so few women are born free and some amid insult and scarlet letters achieved freedom; but our Women in Black had freedom thrust contemptuously upon them. "With that freedom they are buying an untrammelled independence, and dear as the price they pay for it, it will in the end be worth every taunt and groan. (234) Toni Morrison has vividly portrayed the condition of Sethe in Beloved. The cruel situations of the plantations at Kentucky is painfully narrated in her novel. The slave women are immersed in physical and emotional fetters of life.

The position of sethe is very pathetic. Even her shake slavery wasn't really for herself. Her swollen breasts and therefore the baby kicking within pressed her onward to the 
Impact Factor: 4.845(SJIF) Research Journal Of English (RJOE) Vol-5, Issue-2, 2020

www.rjoe.org.in An International Peer-Reviewed English Journal

ISSN: 2456-2696

Indexed in: International Citation Indexing (ICI), International Scientific Indexing (ISI), Directory of Research Journal Indexing (DRJI) Google Scholar \& Cosmos.

baby expecting her milk. Biological necessity made her create a life that might allow her children to get older. Sethe carries Beloved on her conscience and in her heart. For the mother, the dead child is maternity in potentia, the mother truncated. Sethe curses her own future by bitterly remembering her past until she conjures the past; the baby ghost haunts her sons and that they run away, right out of the house unable in touch the fear and uncertainty, isolating her into a completely female realm. Sethe further fixates on the past by never mingling with the Black community, by protecting the only child who stays with her, her daughter Denver, from the past without seeming ever to think of the girl's future or need for community.

When we first enter the house, only Sethe and Denver inhabit it, and it's claustrophobic indeed. More pathetic is the state when the infant dies, Sethe trades her body in a sexual exchange with the, engraver to have the letters engraved on her dead daughter's tombstone. Toni Morrison's women are linked by a 3 generation chain of scars, marking both bond and breach. Sethe's mother urges her daughter to acknowledge her body in death by the scar under her breast, and Sethe's resurrected daughter bears on her neck the mark of her mother's handsaw". Between them, Sethe has "a chokecherry tree" on her back, the scar of a brutal whipping. The School teacher's nephews whip Sethe for reporting their first act of violence against her-the one which looms much larger in her memory, forcibly 'nursing' her breast milk. The tree is thus associated with Sethe's violated motherhood, the visible sign of the crime she repeatedly laments. She remembers with depressed heart when the school teacher and his nephew tied Sethe down, beat her and suckled her breast "they took my milk!" (B 17).

Sethe's life thought and feelings go un-strengthened. "Her meaningless life unanimated makes her feel dry, fatigued and frail in spirit. Sethe represents the slave women world which always bears the seeds of oppression from their birth, even though they give birth to mankind they are treated as only 'Breeders'. They are discarded and degraded. They seem to possess been framed for men and add the sector . In a very emphatic way, Morrison uses Beloved to show in painful detail one of the ways Black women's bodies were "scarred and dismembered by slavery and then salvaged and remembered within the acts of extramarital sex ." (Ashraf Rushdy 102). The novel is a few love relationship gone awry between mother and daughter. Women as mothers had the best psychological blow within the American slave culture. The practice, which denied the women the opportunity and privilege of loving their children, only served to alienate them from their children. Susan Willis avers, "The tragedy of a woman's alienation is its effect on her as mother. Her emotions split, she showers tenderness and love on her employer's child, and rains violence and disdain on her own (265). The type of love relationship between mother and daughter in this novel is also suggestive of the unusualness and complexity of Toni Morrison's art. She has been credited with creating characters with dual and moral uncertainties. In an interview, she calls her fictional characters : The combination of virtue and flaw, of good intentions 
Impact Factor: 4.845(SJIF) Research Journal Of English (RJOE) Vol-5, Issue-2, 2020

www.rjoe.org.in An International Peer-Reviewed English Journal

ISSN: 2456-2696

Indexed in: International Citation Indexing (ICI), International Scientific Indexing (ISI), Directory of Research Journal Indexing (DRJI) Google Scholar \& Cosmos.

gone awry, of wickedness cleansed and people made whole again”. If you judge all of them by the simplest that they need done, they're wonderful. If you judge them by the worst that they need done, they're terrible. (McKay 423)

As Taylor observes : 'Sixty Million and more', is that the inscription at the start of the novel Beloved, written by Morrison. She Morrison devoted Beloved to the roughly sixty million people that died during the slave traffic and who never experienced slavery. "These victims never experienced the long disturbing and psychologically painful period that Africans and generations thereafter had to endure. Although the book is dedicated to those who died in the Atlantic trade, however, its story serves to memorialize the institution of slavery itself as it existed in the United States. According to Morrison, there's a necessity for remembering the horror, but in fact there's a necessity for remembering it during a manner during which it are often digested, during a manner during which the memory isn't destructive. The act of writing the book, in a way, is a way of confronting it and making it possible to remember. (248) In other words, Morrison argues that overcoming the trauma of slavery entails remembering rather than forgetting. In contemporary American culture the institution of slavery has been largely forgotten. But Morrison tries to show that the past never ends. She wants the readers to re-vision and understand African-American history through non-western eyes by re-telling history through the lives of former African slaves. Beloved takes place in 1873, during a house in Cincinnati, Ohio.

Sethe, a former slave, and her daughter Denver are the sole women living within the house, besides the ghost that haunts them. It has been a few years since Sethe escaped from the farm 'Sweet Home' in Kentucky, where she had lived as a slave. While pregnant, Sethe had made plans to run away from the farm with her husband Halle, with the intention of fleeing across the Ohio river to Halle's mother, Baby Suggs, in Cincinnati. Their three children were already living with Baby Suggs". However, on the day of the escape, Halle was nowhere to be found and Sethe was forced to flee alone. On her way to Ohio she delivered a baby girl, but otherwise arrived safely at Baby Suggs' house. For Sethe, living in freedom with her mother-in-law and her four children lasted only for a short period of time, as her master ruthlessly hunted her down in an attempt to reclaim his property. When he finally found her, Sethe attempted to kill her children to avoid enslavement for them, but she only managed to kill one daughter. "The ghost now haunts the house where Sethe and Denver live. Little by little we learn about Sethe's past through her conversations with Paul D., one of the other slaves from 'Sweet Home' who visits Sethe to remember about old times. According to Dolan Hubbard, the novel Beloved is centred on "the historical incontrovertible fact that there have been Black women during slavery who terminated their babies' lives instead of allow them to be offered up to the destruction of slavery (137).

Through the flashback technique "with a sympathetic omniscient narrator", we are presented with the tragic story of Sethe who escapes from slavery in Kentucky, "but is 
Impact Factor: 4.845(SJIF) Research Journal Of English (RJOE) Vol-5, Issue-2, 2020

www.rioe.org.in An International Peer-Reviewed English Journal

ISSN: 2456-2696

Indexed in: International Citation Indexing (ICI), International Scientific Indexing (ISI), Directory of Research Journal Indexing (DRJI) Google Scholar \& Cosmos.

haunted by profound guilt over killing of her daughter, whose ghost traumatizes the family" (B 138). Sethe kills her daughter because she loves her such a lot that she doesn't want her daughter Beloved to 'die' - undergo slavery as she has. This death kills both body and soul. However, the love that imputes this kind of logic in Sethe's head is a strange type of love.

Toni Morrison suggests that Beloved can be read in two ways, both as a psychically damaged real-life slave girl and as a ghost (fantasy object for the emotions of others). "According to classical psychoanalysis, children begin at this age to undergo the oedipal crisis, which should instigate their development into separate selfhood. Normally, the oedipal crisis is meant to properly socialize the kid into imbibing the norms of its surrounding family, society and culture. This process always involves repression of unwholesome desires. Certain importunate demands, inappropriate behaviour by the code of the given society are streamlined in this socialization process, so that the child should be able to differentiate between acceptable and unacceptable behaviour in his or her environment". By Beloved's death at the age of two, this process of psychological development is terminated and she is by implication denied the privilege and opportunity of entry into Melanie Klein's depressive position, where she would mature properly into culture and make reparation to her mother for her monstrous behaviour.

Another important implication of this failure to enter the depressive position is that Beloved's psychological development is still within the preoedipal stage where there is still a symbiotic relationship with the mother. Beloved still clings tenaciously to her mother and does not therefore have an independent existence. Her dependence on Sethe is such that she expresses aggressively whenever Sethe fails to align her thoughts with hers: And it was so much better than the anger that ruled when Sethe did or thought anything that excluded herself. She could bear the hours - nine or ten of them each day but one - when Sethe was gone. (100)

Sula centers round the 'sisterhood' concepts, a sister kinship which yokes the 2 women together -" Sula and Nel. Both are drawn as a foil to every other. Sula emerges as a character unlike any other kind, in getting into her own queer way, she announces her freedom, however Sula in her quest for autonomy, becomes the personification of both the potential of a black woman and ironically, the pariah of her community, Nel on the other hand gives up her ambition of leaving the Bottom society for the sake of her husband and youngsters, reducing herself to the expected role of a wife and mother. It describes how their deep bond is battered by societal pressures. Sula and Nel are together in every act they do in their adolescent age. The girls also have a mysterious secret because they play a part in the accidental death of a young boy named, Chicken Little. Their friendship continues even after this incident. The novel describes the different ways present in front of the Black females to follow. One choice is to live traditionally as part of the society or the other choice 
Impact Factor: 4.845(SJIF) Research Journal Of English (RJOE) Vol-5, Issue-2, 2020

www.rjoe.org.in An International Peer-Reviewed English Journal

ISSN: 2456-2696

Indexed in: International Citation Indexing (ICI), International Scientific Indexing (ISI), Directory of Research Journal Indexing (DRJI) Google Scholar \& Cosmos.

is to live a revolting life, isolated from the African community. It is also a story of motherliness, friendship, sisterhood and love". After Sula has an affair with Nel's husband, she is unable to speak to Nel, and she spends her life of seclusion in Medallion. "She is hated and shunned by the people of Medallion as a devil who would sexually seduce their males. Then Sula's illness brings the two women closer again. They argue further upon the unconventional life sort of Sula. Nel becomes further frustrated by Sula's attitude towards conventionality and tradition. Sula dies alone in her home after Nel leaves out. After Sula's death, the people of Medallion are pleased. They abandon their righteousness and become relaxed in performing their, duties as,mothers and daughters. Pin-chia -Feng argues for the textual construction of identity in novels by African American writers centering on minority women in a society "permeated by race, class and sex / gender oppression" (2).

Sula fails to seek out her own identity though, there's great assertion in her outlook and action. She is all that Nel is not. Traditional feminists criticism interprets the intimate relationship between Sula and $\mathrm{Nel}$ as resembling that of the nurturing bond between mother and daughter and just 'as a substitute for the lost sense of kinship within the post-diasporic Black community. Toni Morrison draws the 2 female characters drawn together out of a shared, lived experience as Black women during a white patriarchal society. Sula returns to the Bottom after an absence of ten years, her sexual exploits and indiscriminate manner of stealing husbands, be it even the mate of her close friend Nel, Sula does it without any regret or remorse. Her sexual indulgence alienates her from the rest of the community. Her audacity stands strong in refusing to enter the conventional marital ties or to conform to the heterosexual formativeness of marriage. Sula's relationship with Nel breaks under the strain of Sula demanding all from Nel, where Nel expects nothing from her, Nel comes to a stage where she is unable to tolerate the exploits of her friend, when it crosses a particular limit, she too just like the remainder of the community, turns her back to Sula". Despite having travelled the country and gained a college education, Sula is still rejected and ostracized because she obstinately refuses to confirm to the ideology of Black womanhood to which Nel bows down. The ending of an intimate relationship, presents their inherent differences, they drift away, totally alienated from one another. It may be a fter Sula's death that Nel realizes that their friendship is a bond which nurtures the development of a replacement privileged Black womanhood.

Sula may be a text which deals with the interrelationship between gender, class and race. "Toni Morrison strives to create in this novel a social order which the black women attempt to structure but are defeated by their slave and race identity. Both Sula and Nel are lonely individuals and essentially fail to connect with the other Blacks around them, they can however connect with each other spiritually and in a kinship supporting and sustaining each other as is implied in Sula's speech that heterosexual bond is fickle and unstable because of the male ego, whereas the female friend is reciprocal and enduring. This is till 
Impact Factor: 4.845(SJIF) Research Journal Of English (RJOE) Vol-5, Issue-2, 2020

www.rjoe.org.in An International Peer-Reviewed English Journal

ISSN: 2456-2696

Indexed in: International Citation Indexing (ICI), International Scientific Indexing (ISI), Directory of Research Journal Indexing (DRJI) Google Scholar \& Cosmos.

Sula betrays Nel by stealing Jude from her. It is however claimed that though Toni Morrison created Sula as a tragic character who fails to negotiate her own identity, her character carries weight as Sula emerges as a role, model for women at large, implementing among women a notion of kinship and unity particularly among Black women as a means of recreating a lost community, more of a 'womanist' than a 'feminist' in her relationship with Nel. What makes Sula deny Nel is her loss of identity. Now Nel belonged to the town and every one of its ways. She had given herself over to them, and therefore the flick of their tongues would drive her back to her little dry corner where she would hold close her spittle high above the breath of the snake and therefore the fall. It had surprised her a touch and saddened her an honest deal when Nel behaved the ways the others would have".

What ostracizes Sula from the rest of the Black Community is their conformity their 'hooded' self at any new private thoughts the dreads, their narrow lives and when she chooses to differ, the knife comes down on her, she was a pariah and she knew it "Knew that they despised her and believed that they framed their hatred as disgust for the straightforward way she lay with men" (S 122). Sula's sexuality is her way of connecting with men, but after a passage of time, the turbulence of her sexuality gives way to a silence . As Mckay points out: There within the center of that silence wasn't eternity but the death of your time and loneliness so profound the word itself had no meaning. For loneliness assumed the absence of people, and therefore the solitude she found therein desperate terrain had never admitted the likelihood of people . (123) "Sula's deviance from the conventional, the accepted social norms is her inner craving for recognition, to be someone with a definite identity, even her gesture of depriving off her best friend of her husband is a deep yearning, anguished cry from her lonely friend though she feigns a bold metallic façade, inside she longs to be loved, to be owned and respected. Her love for Ajax is one such relationship which provides her a deep feeling of being wanted. His departure empties her. She is barren of all emotions as if his departure has ripped from her, her vital entrails her life and her breath itself. She moans: There aren't any more new songs and I have sung all the ones there are. I have sung them all. I have sung all the songs there are. She lay down again on the bed and sang a touch wandering tune made from the words I even have sung all the songs all the songs I even have sung all the songs there are until, touched by her own lullaby, she grew drowsy, and within the hollow of near-sleep she tasted the acridness of gold, left the coolness of alabaster and smelled the dark sweet stench of loam”. (137)

When Nel strides call at anger with Sula, deeply hurt that Sula had not spared her husband, Sula sinks into fond memories of her old flame. So she is going to walk on down that road, her back so straight therein old green coat, the strap of her handbag pushed back all the thanks to the elbow, thinking what proportion I even have cost her and never remember the times once we were two throats and one eye and that we had no prices. (147) To Sula's query if they were still good friends, Nel angrily retorts, "You laying there in that 
Impact Factor: 4.845(SJIF) Research Journal Of English (RJOE) Vol-5, Issue-2, 2020

www.rjoe.org.in An International Peer-Reviewed English Journal

ISSN: 2456-2696

Indexed in: International Citation Indexing (ICI), International Scientific Indexing (ISI), Directory of Research Journal Indexing (DRJI) Google Scholar \& Cosmos.

bed without a time or a friend to your name having done all the dirt you probably did during this town and you continue to expect folks to like you? (145). "To the close of her life, Sula's alienation from all-her best friend Nel, Ajax, her lovers and the community, is complete. Her dying is brutally lonely. It is the whites who come to the fore to rearrange for her funeral. As P. Hunt points out: Toni Morrison interrelates gender, class and race by creating situations which concentrate on the way in which black women attempt to structure their own social orders but unto are limited by their class and race identified. Sula foregrounds the conflicted status of race and gender impact slavery in American culture. The 'Bottom' represents a form of government which has enslaved nation, emancipated people, enfranchised them, and disenfranchised them". (459)

Like Harlem, Bottom is additionally an isolated Black grotto, where the racially alienated people are forced to measure . But Morrison doesn't simply linger over the matter of being 'Black' the racism they're subject to. Her novel Sula also details the predictable political social and economic changes that are ushering in bringing along with them an impact on the lives of the black people as well. With Sula's death, racial apathy and isolation seem to be collapsing, with economic empowerment of the Black comes, growth and development. The first thing is the promise of work of the tunnel, next was the construction of an old people's home, all these changes instilling in the Black people a strong sense of hope. Even the lonely Shadrack comes to life. Bottom has collapsed with people, with money approaching the valley, and white people were building homes in the hills, the community, has yielded to "separate homes with separate televisions and separate telephones and fewer and fewer dropping by" (S 166).

The novel closes with Nel realizing their friendship has actually been a bond which nurtures the construction of a new, privileged black Woman hood. At the end there is no Black or white or race class or gendered that mattered $\mathrm{Nel}$ in an anguished voice calls out from what matters to her most- "O Lord Sula", she cried, "girl, girl, girl, girl, girl" (174), "a siren that rises from the pit of being without a top or bottom an endless circle of sorrow lashing her. Morrison's novel The Bluest Eye centers around a black girl's desire for the bluest eyes, Pecola in her worthless state craving for the impossible becomes a metaphor of what it is to be Black, poor and ugly. The Bluest Eye is about the contradictions fostered by racism, sexism and sophistication distinctions that assail the black. The contradictions are too intense for Pecola to sustain her sense of worth as an escape from a highly intolerable situation, she sinks into madness. The other girls Claudia and Frieda manage to survive. The novel also shows the tragic effect of race prejudice on children. The novel basically underlines the principle that 'to be black was to be a victim'. Pecola is a victim of the vicious genocidal effects of racism on a Black girl. Much of Toni Morrison's novels experiment with the concepts of class and its relation to sex and race which forms an integral part of many of her novels. In Sula's refusal to be a part of community, be good and be 
Impact Factor: 4.845(SJIF) Research Journal Of English (RJOE) Vol-5, Issue-2, 2020

www.rioe.org.in An International Peer-Reviewed English Journal

ISSN: 2456-2696

Indexed in: International Citation Indexing (ICI), International Scientific Indexing (ISI), Directory of Research Journal Indexing (DRJI) Google Scholar \& Cosmos.

accepted by everyone, she unconditionally refuses that race and steps outside the cast of women beyond any class definition within that cast, she does not work and is not interested in men, she defies the male concept of beauty and demolishes the seared forms of motherhood, she defines herself outside of the sex, class, race, deprivation of the society.

Sula and her grandmother Eva, share an excellent deal in common, both leave range in medallion's 'Bottom' and return only to inhabit willful isolation. Both are indifferent to like and have caused the death of another. One of the worst effects of historical transition for a 'used to be slave mother' was alienation and repression". Sethe's alienation isn't the result of her separation from her family or the social cultural mores but thanks to murdering her own daughter to save lots of from living an abject life as a slave. Like Sula, Sethe is an outcast, an outlaw, like her, Sethe does not care for the society but seeks to assert a sense of self. The 1930's saw the growth of capitalism an age of increased production and consumerism between the two, there was a spread of feelings of desperation, isolation and alienation. As pointed by Zhong Wang.

\section{Conclusion:}

The social background of Beloved is additionally left in an alienated world of slavery. "The characters in Beloved share alienation and exile either psychologically or physically under the oppressive world dominated by the white standards. Sethe and Paul.D represent the twisted absurd people who live in absurdity and rebel against the absurdity through their action escaping from slavery both physiologically and psychologically therefore achieve the freedom eventually. (71) The Afro - Americans had experienced a bitter part of slavery. Beloved presents cruel picture of Afro-American slavery within the (19th. Arriving at a strange place, an alien culture, the Blacks were subjected to a horrific history of repression and marginalization. The worst aspect was that the Blacks were treated as sub-humans and next to animals and were made to work and were subject to hard laborious work. Millions of Blacks died tragically in middle passage.

If the condition of the Black male was unmanageable and unredeeming, for the Black woman, the condition would be simply unspeakable. Women slaves were loosely used and often raped by their white owners; the final ignominy was that the black women did not own their own children. Their children did not belong to them, the children removed from their mothers were objects of cruelty, as they were defenseless passive and vulnerable. Most Black men and ladies unable in touch the shifting oppression within the south, strove to migrate to the economic North, a freer place where they felt, they might lead an economically and socially elevated life. But they were again proved wrong". They were distressed to job opportunities and that they countered a special set of difficulties. The white racist discrimination again alienated them from conforming to any system. 
Impact Factor: 4.845(SJIF) Research Journal Of English (RJOE) Vol-5, Issue-2, 2020

www.rioe.org.in An International Peer-Reviewed English Journal

ISSN: 2456-2696

Indexed in: International Citation Indexing (ICI), International Scientific Indexing

(ISI), Directory of Research Journal Indexing (DRJI) Google Scholar \& Cosmos.

\section{References:}

- Ashcroft, B., G. Griffiths \& H. Tiffin, 2007.Post-colonial Studies: The Key Concepts. NY: Routledge.

- Beaulieu, E., 2003. (Ed.) The Toni Morrison Encyclopedia. USA: Greenwood Press.

- Bell, B., 1987.The Afro-American Novel and Its Tradition. Amherst: University of Massachusetts Press.

- Bertens, H., 2008.Literary Theory: The Basics. New York: Taylor and Francis Group. BhabhaHomi, K., 1994,The Location of Culture. New York: Routledge. Bloom, H. (Ed.), 2004.

- Durkin, A., 2009.Bloom's Guides: Toni Morrison Beloved. USA: Chelsea House Publisher's. "Object Written, Written Object; Slavery, Scaring, And Complications of Authorship in Beloved" Toni Morrison's Beloved. Ed. Harold Bloom. NY: Infobase Publishing.

- Freud, S., 2004. The Uncanny. Literary Theory: An Anthology. Ed. Julie Rivkin and Michael Ryan. United Kingdom: Blackwell Publishing. Gillespie, C., 2008.

- Wallinger, H., 2007."Toni Morrison's Literary Criticism." The Cambridge Companion to Morrison . Ed. Justine Tally. United Kingdom: Cambridge University Press. 